\title{
New Paleoindian Finds, Further Fell Points Data, and Technological Observations from Uruguay: Implications for the Human Peopling in Southeastern South America
}

\author{
Hugo G. Nami' ${ }^{1}$, Andrés Florines ${ }^{2}$, Arturo Toscano ${ }^{3}$ \\ ${ }^{1}$ Department of Geological Sciences, Laboratory of Geophysics “Daniel A. Valencio”, CONICET-IGEBA, FCEN, UBA, Buenos \\ Aires, Argentina \\ ${ }^{2}$ Departament of Archaeology, Institute of Anthropological Sciences, Faculty of Humanities and Education Sciences \\ (Universidad de la República), Montevideo, Uruguay \\ ${ }^{3}$ Evaluación de Impacto Arqueológico, Florines \& Toscano (EVIAR), Montevideo, Uruguay \\ Email:hgnami@fulbrightweb.org, aflorine@fhuce.edu.uy, toscanouy@gmail.com
}

How to cite this paper: Nami, H. G., Florines, A., \& Toscano, A. (2018). New Paleoindian Finds, Further Fell Points Data, and Technological Observations from Uruguay: Implications for the Human Peopling in Southeastern South America. Archaeological Discovery, 6, 21-37. https://doi.org/10.4236/ad.2018.61002

Received: October 26, 2017

Accepted: December 24, 2017

Published: December 27, 2017

Copyright $\odot 2018$ by authors and Scientific Research Publishing Inc. This work is licensed under the Creative Commons Attribution International License (CC BY 4.0).

http://creativecommons.org/licenses/by/4.0/

\begin{abstract}
Mainly represented by "fishtail" or Fell points $(\sim 11,000$ - 10,000 uncalibrated years BP), Paleoindian remains in Uruguay are distributed over a wide area. However, just a few stratified sites have yielded evidence of the earliest settlers in this part of South America. Cueva Amarilla was discovered as a result of an intensive survey conducted in the Lavalleja department. Because cave sites in Uruguay are scarce, an evaluation of its archaeological potentiality was performed. Lithic artifacts and charcoal were exhumed from its sedimentary deposits. A sample of the latter yielded a conventional radiocarbon date of 10,000 uncalibrated years BP. This date suggests that Cueva Amarilla witnessed an occupation during the Pleistocene-Holocene transition, which was thus Paleoindian. This date agrees well with the time-span of the Fell occupation in South America in general, and particularly in southern Uruguay. Therefore, this level might have belonged to hunter-gatherer colonizers who used "fishtails" as part of their weaponry. In this regard further "fishtail" points data as well the specimens coming from neighboring departments are reported. In the study area, and around the cave, there are ubiquitous primary and secondary sources of lithic raw materials, mainly significant outcrops of a yellowish/pale-brown siliceous rock, commonly called "opal" or "jasper", which was used since Paleoindian times. Related to the stone tool reduction systems, this material along with other finds from Cueva Amarilla is discussed from a technological perspective. The finds from this cave along with the Fell
\end{abstract}


point finds from the region, are discussed within the framework of the colonization process of South America.

\section{Keywords}

Paleoindian, Lithic Technology, Fell Points, South America, Uruguay

\section{Introduction}

During the human colonization of the Earth, the Americas were the last continents to be colonized during the Late Pleistocene, within a time span that is subject to debate (Meltzer, 2013). Nevertheless, by approximately 11,500-10,000 uncalibrated radiocarbon years BP ( 11.5 - 10 ky BP hereafter $)$, it is an undisputed fact that the New World was inhabited from Alaska to Tierra del Fuego (Graf et al., 2013; Nami, 2014). Henceforth called Paleoindian or Paleo American, the archaeological remains from that time show that Clovis-the oldest fluted point-had spread throughout North America by $\sim 11.5$ to $\geq 10.8 \mathrm{ky}$ BP (Waters \& Stafford, 2007). Similarly, in South America, the "fishtail," "Fell's cave," or just "Fell" point (FP) is a widespread lithic marker dating from between 11 - 10 ky BP (Maggard \& Dillehay, 2011; Nami, 2007; Waters, Amorosi, \& Stafford, 2015; Nami \& Stanford, 2016; Yataco \& Nami, 2016; Prates et al., 2013). It has been reported from south-central Mexico and Central America to southernmost South America (e.g., Bell, 1965; Cassiano \& Alvarez Palma, 2007: Figure 10; Pearson, 2004; Flegenheimer \& Weitzel, 2017; Nami 2014, 2016a, 2016b), but it is most commonly found in the southern cone of South America (Flegenheimer \& Weitzel, 2017; Nami, 2014). One of its densest concentrations was found in its mid-central portion, north and south of La Plata River (Nami, 2016a). North of this estuary, there have been mostly surficial finds in an area currently occupied by the territories of northeastern Argentina, Uruguay, and southern Brazil; and to the south in several stratigraphic sites in Buenos Aires province, in east-central Argentina (Flegenheimer \& Weitzel, 2017; Nami, 2016a; Suárez, 2015; Loponte et al., 2015; Loponte et al., 2016; Loponte \& Carbonera, 2017). As part of this large geographical area, recent investigations performed throughout Uruguay have added new information to the discussion of its oldest human occupations. In this line of research, it is helpful to know the chronology and dispersion of the early colonizer hunter-gatherers in South America, and this paper provides information about recent discoveries and data from southeastern Uruguay (Figure 1).

\section{General Remarks}

The Republic of Uruguay is located in the mid-eastern part of the southern cone of South America. Despite being a small country of $176.215 \mathrm{~km}^{2}$, archaeological research shows huge variations across its nineteen territorial departmental 


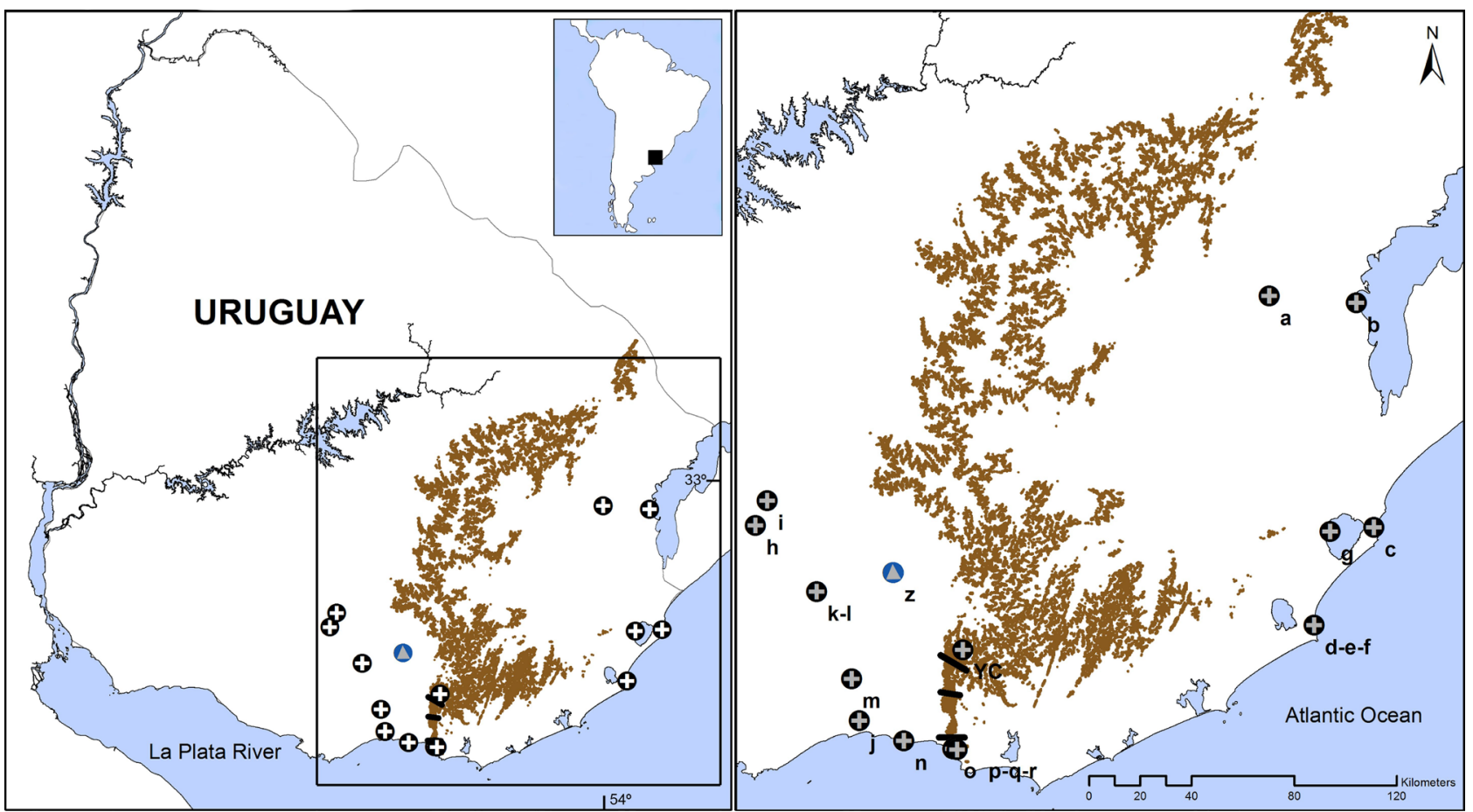

Figure 1. Location map of Cueva Amarilla in southeastern Uruguay (shown as the black square in South America) and sites with Paleoindian finds surrounding the Lavalleja department; the letters shows the Fell points' localities, as depicted in Figure 7. YC: Cueva Amarilla, z: Los Ciervos. The black lines near YC indicate the Abras of Zavaleta and Castellanos, and Paso Punta de la Sierra (figure by A. Florines).

divisions. Many investigations have been performed in its eastern and southeastern areas (Consens et al., 1995, Durán Coirolo \& Bracco Boksar, 2000; LópezMazz et al., 2003-2004). However, our study area, situated in the Lavalleja department, has only received a few contributions (Fernández, 1977; Toscano, 1983; Cavellini, 1984; López Romanelli, 2012).

Paleo American remains in Uruguay are distributed throughout the country. Archaeological research is carried out on vestiges recovered from buried and surface records; remarkably, a significant portion of the evidence consists of fishtail specimens. In this regard, the Uruguayan territory has one of the greatest densities in South America. They were recovered from stratigraphic (Meneghin 2015), but mainly surface finds (Castiñeira et al., 2011; López-Mazz, 2013; Suárez, 2015; Nami, 2013, 2015a, 2016a, 2017; among others).

From a geological viewpoint, the study area is located in the Late Precambrian Dom Feliciano Belt (Basei et al., 2000). This is a magmatic belt that extends in a SW-NE trend through Uruguay and southern Brazil. It is mainly composed of a variety of granitoids intruded in low-grade igneous and metamorphic rocks (mainly granites, phyllites, schists, and quartzites). It is a few dozens of $\mathrm{km}$ wide and is characterized by elevations averaging between 200 and $300 \mathrm{~m}$, and a few exceptions that are higher such as the Cerro Pan de Azucar, near Piriapolis. The most conspicuous orographic system in the area is the Sierra de las Animas, which limits the Dom Feliciano Belt in the east and is composed of latest Pre- 
cambrian to Cambrian volcanic and hypabyssal rocks (Sánchez Bettucci, 1998). The surveyed area shows an extremely faulted and folded sequence, resulting in a complex context with abrupt lithological variations. The landscape is basically made of a series of low-grade metamorphic rocks that mainly include quartzite, quartz, quart schists, and schists that are intruded by a pink/yellowish granite that is exposed in the tallest hills in the region. On the other side, quartzite outcrops are characterized by medium-size hills, some with steep slopes and pointy rock exposures. Schists appear, forming rounded hills with gentle slopes (Angel Ambiental, 2009).

\section{Results and Discussion}

With the aim of evaluating the archaeological impact from the construction of a wind farm, an intensive survey was conducted in 2012-2013 in an area located south of Salus Park (Toscano \& Florines, 2013). As a result of this activity, a small cave was discovered in one of the low hills made of yellow rock, and for this reason it was called Cueva Amarilla (CA) or Yellow Cave. Situated in a high part of the rocky outcrop at $\sim 300 \mathrm{~m}$ asl, it is preceded by an easily accessible hillside ending in a small permanent water runoff that runs to the foot of the slope in a North-South direction (Figure 2). Facing South-East, this cave is a small refuge $9.50 \mathrm{~m}$ deep that was probably affected by a wall collapse that significantly reduced its habitable size (Figure 3). Two points of access with a gentle slope are delimited by a large rock. The main one has an easily accessible entrance with a width of $1.75 \mathrm{~m}$ and a height of $1.51 \mathrm{~m}$; the other is 1.10 by $1.03 \mathrm{~m}$ in width and height, respectively. It is worth mentioning that currently they are only visible from a close distance on the hill. In the same outcrop, a smaller shelter was identified close to CA.

Lithic artifacts were discovered on the surface of the sedimentary deposit in the main sector. Because of this, and the fact that this kind of site is extremely rare in Uruguay, the authors planned a visit to evaluate and estimate its potential for excavation. Accordingly, additional exploration surveys and two test units of $0.50 \mathrm{~m}$ by $0.50 \mathrm{~m}$ were performed in 2015 . The first, located near the point of access, showed that the bedrock was at a shallow depth and did not yield any archaeological vestiges. However, in its inner part, the second unit had a sedimentary deposit $0.55 \mathrm{~m}$ deep on the cave's bedrock and abundant archaeological remains. At a lower level, numerous lithic artifacts were found that were associated with a significant quantity of charcoal mixed with a black carbonaceous sediment (Figure 2(f)). A portion of the charcoal sample (Figure 4) taken from $40 \mathrm{~cm}$ below the surface was submitted to Beta Analytic Inc. (Miami, Florida, USA) for radiocarbon dating. Using the AMS method, a Conventional Radiocarbon Age of 10,000 \pm 30 BP (Beta 464524) was obtained. This date was corrected using the BetaCal 3.21 program based on the probability method developed by Bronk Ramsey (2009), and the ShCal 13 curve for the southern hemisphere (Hogg et al., 2013), thus producing the histogram shown in Figure 5. 


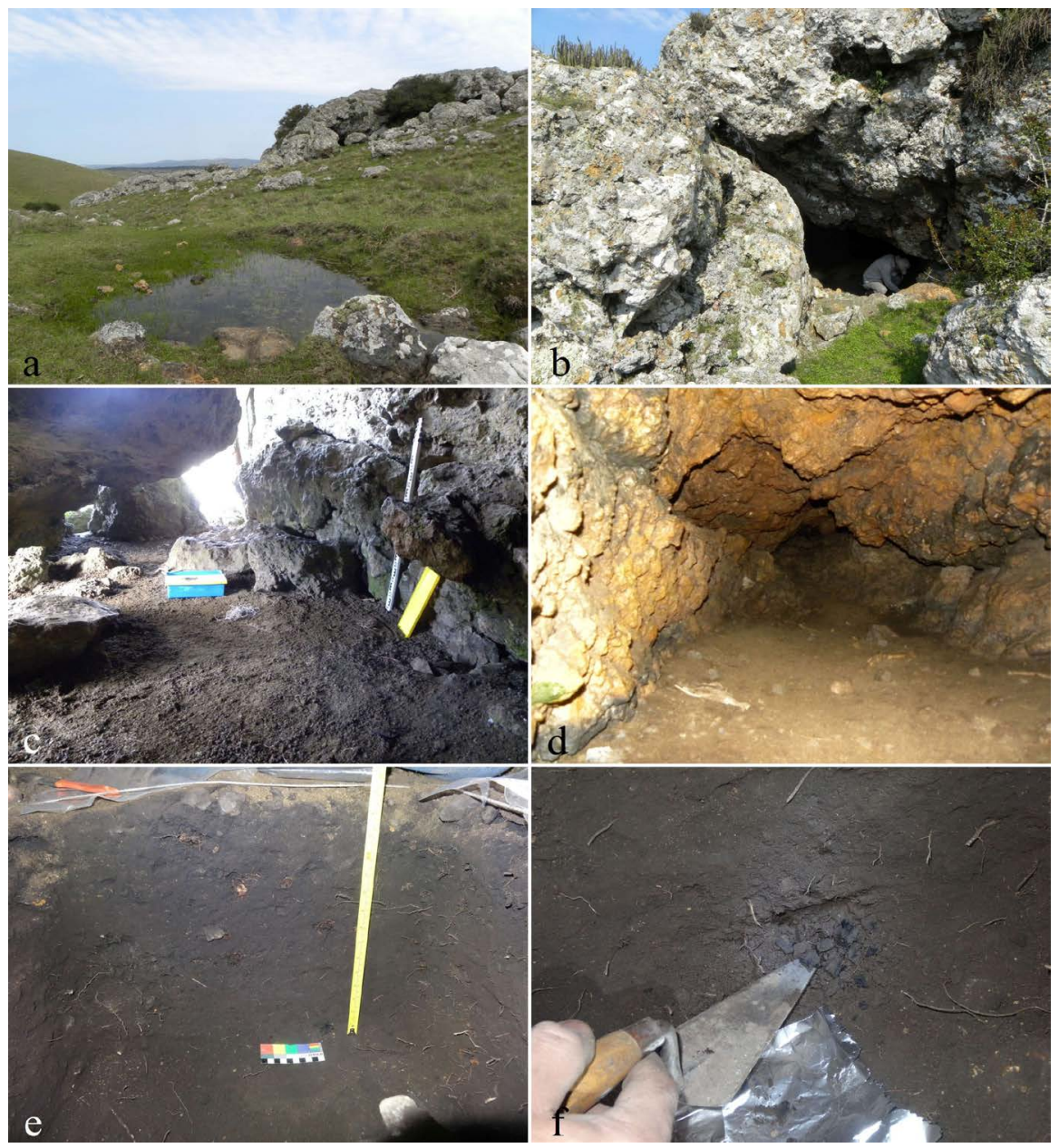

Figure 2. Different views of Cueva Amarilla and the test unit. (a)-(b) Front and access, (c) inside view of the entrance, (d) inner portion, (e)-(f) sedimentary section and charcoal embedded. Photos by A. Florines and A. Toscano.

Table 1 shows the calendar-calibrated ranges at the $95.4 \%$ and $68.2 \%$ probability levels, along with the percentage probabilities for the multiple ranges.

At a similar depth of the charcoal, and deeper, two nucleiform artifacts, an end-scraper, and a debitage were exhumed (Figure 6(a)-(h), Figure 6(l)). The large nucleiform was formed by percussion flaking on a local white fine-grain quartzitic rock with a lot of fissures that impeded adequate flake detachment. It also shows that on one part of the striking platform there is a rounded edge (Figure 6(a), Figure $6(\mathrm{~b})$ ), which might have resulted from it being rubbed with the aim of eliminating the overhands of the previous flake detachment (Crabtree, 1972), or its use as a functional scraping tool (Hester \& Heizer, 1972; Salls, 1985). Because this is limited to a small part, it was possibly due its alternative use of platform preparation. Despite the material flows, this large artifact was probably made for a functional purpose. In fact, the choice of a piece of rock with many and evident flows probably did not represent a problem for the craftsmen, whose intention was to shape an expedient tool (Binford, 1979), a fact that needs further investigation. The remainder of the archaeological vestiges are 


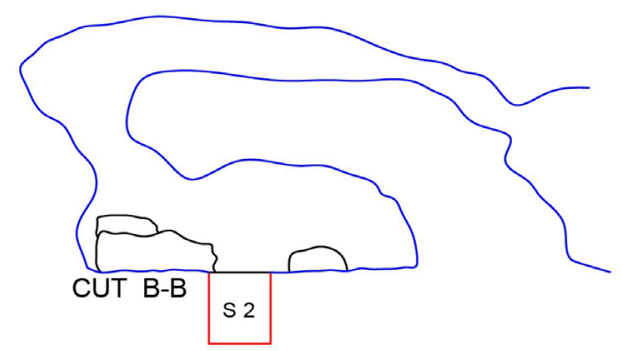

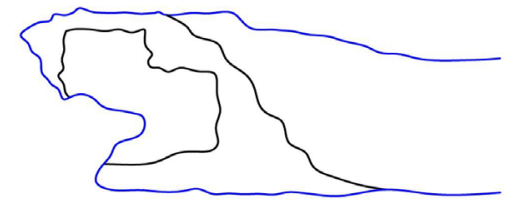

CUT C-C

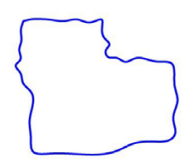

CUT D-D
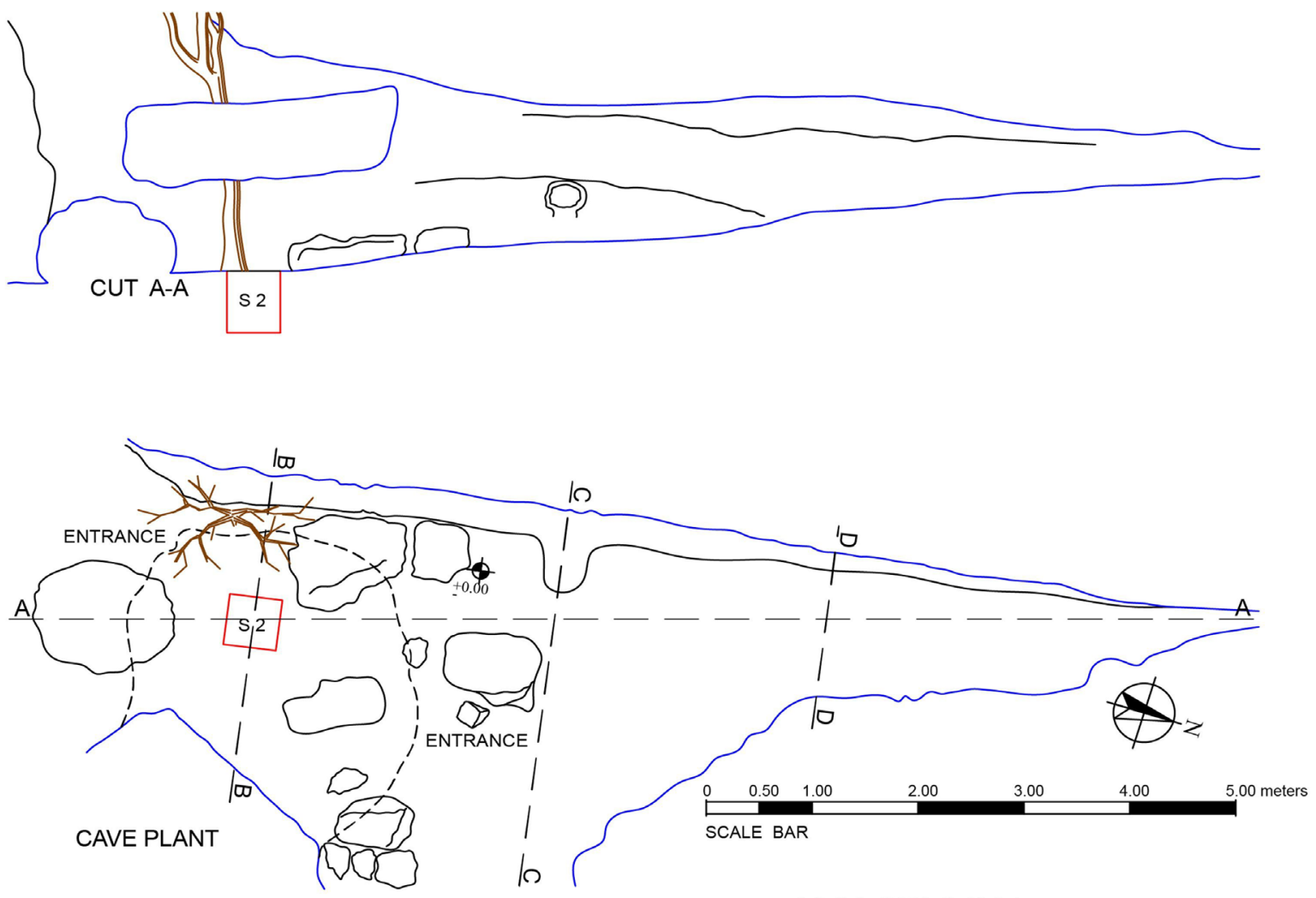

YELLOW CAVE

CAD: E.Villagrán

Figure 3. Plan of Cueva Amarilla (graphic design by E.Villagrán).

quarzt and "opal" waste represented by debitage as a result of working the nucleiform artifact, and shaping and/or rejuvenating tools (Andrefsky, 2002), among which are bifacial thinning, retouching flakes (Figure 6(e)-(h), Figure 6(l)) that were detached by soft percussion (Nami, 2010: Figure XIVa; 2017: Figure 14-15), and pressure flaking. Interestingly, there is a flaked piece made of silcrete (Figure 6(c)), a much-used rock by early foragers (Nami, 2016a).

The date of $10 \mathrm{ky}$ BP suggests that CA witnessed an occupation during the Pleistocene-Holocene transition, which was thus Paleoindian. This date agrees well with the time-span of the Fell occupation in South America in general, and particularly in southern Uruguay (Nami, 2016a: Table 2). Therefore, this level might have belonged to hunter-gatherer colonizers who used "fishtails" as part 


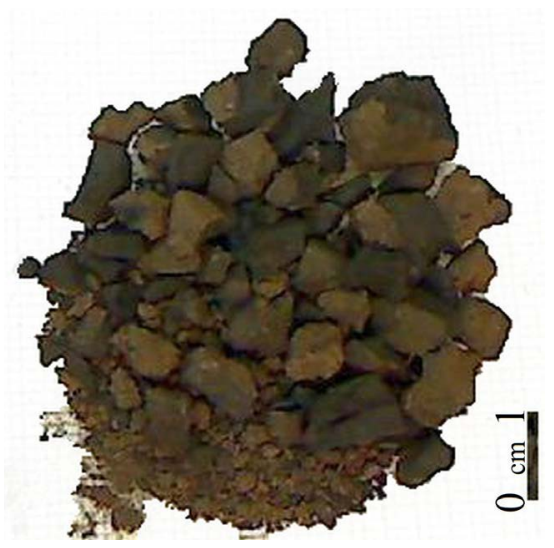

Figure 4. Charcoal sample from CA submitted for radiocarbon dating (from Beta Analytic Inc).

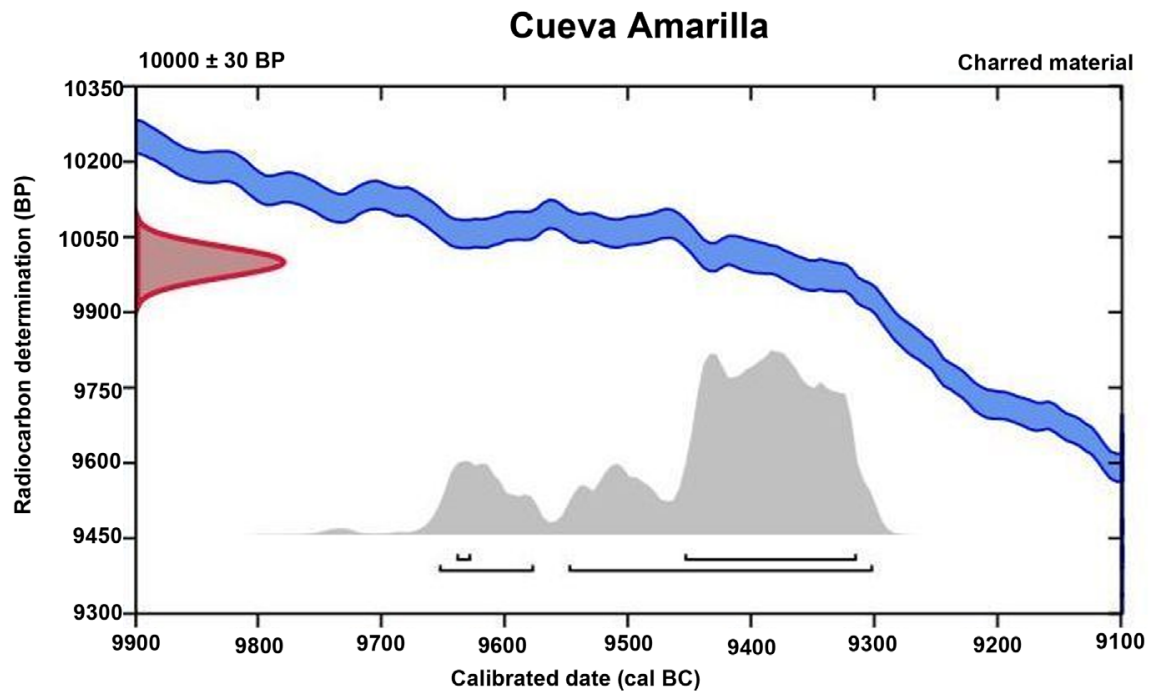

Figure 5. Plot showing the AMS date of 10,000 \pm 30 14C yr BP (Beta 464,524) for Cueva Amarilla, as well as the $95.4 \%$ and $68.2 \%$ probability calibrated age ranges and the ShCal13 curve for the southern hemisphere (from Beta Analytic Inc.).

Table 1. Range of calibrated ages for the Cueva Amarilla date.

\begin{tabular}{ccccc}
\hline Uncalibrated age & \multicolumn{2}{c}{$68.2 \%$ probability } & \multicolumn{2}{c}{$95.4 \%$ probability } \\
\hline Years BP & Years BC & Years BP & Years BC & Years BP \\
\hline \multirow{2}{*}{$10000 \pm 30$} & $9456-9316(65.5 \%)$ & $11,405-11,265$ & $9550-9303(82.5 \%)$ & $11,499-11,252$ \\
& $9641-9629(2.7 \%)$ & $11,590-11,578$ & $9655-9578(12.9 \%)$ & $11,604-11,527$ \\
\hline
\end{tabular}

of their weaponry ${ }^{1}$. Despite the fact that they were not found at Lavalleja, a number come from neighboring departments (Figure 1(c), Figure 7). They

${ }^{1}$ Other Holocene Umbú like projectile points (Dias Schmidt, 2007, Bueno et al., 2013) with similar dates to FPs were found in sites along the coast of the Uruguay river in southern Brazil and NW Uruguay (Miller, 1987; Hilbert, 1985; Suárez, 2015; Moreno de Souza, 2017). However, this data must be taken with caution in light of alluvial geo-archaeology and site formation process (Nami, 2013, Feathers \& Nami, 2017). Then, preliminary and tentatively, we think that the dated CA archaeological remains belong to the FPs makers. 


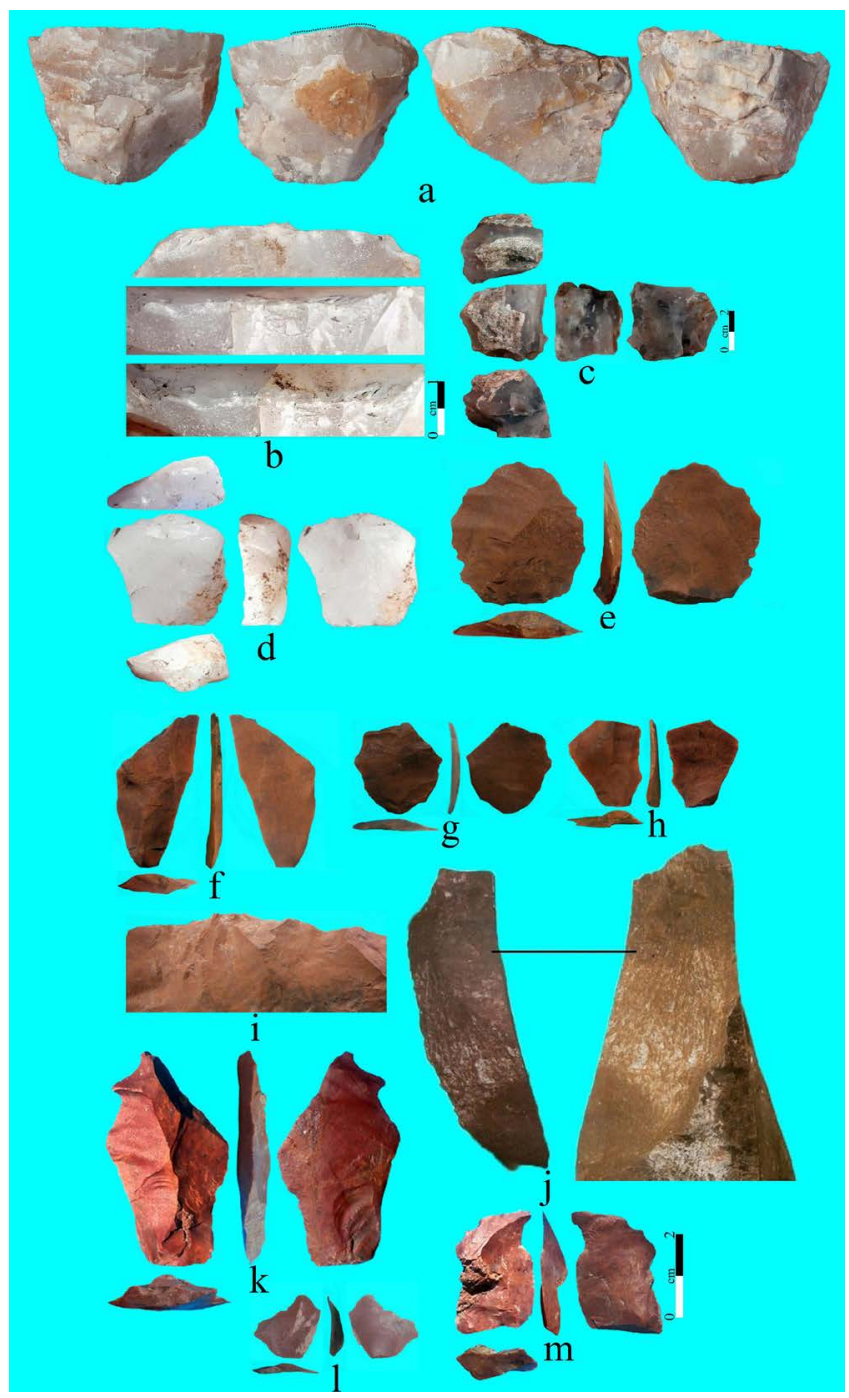

Figure 6. (a)-(h), (l) Lithic artifacts from Cueva Amarilla: (a) and (c) nucleiforms; (b) close-up view of the rounded edge depicted with a pointed line in (a), (d) end-scraper; (e)-(h) and (l) debitage, (i)-(m) heat-treated "opal": (i)-(j) experimental specimens showing the change of color in (j); (k)-(m) archaeological (photos by H. G. Nami).

were documented in Rocha to the east; in Canelones and Maldonado to the south, and in Florida to the west (Figueira, 1892, López-Mazz, 2013; Nami, 2015, 2016a). $38 \mathrm{~km}$ south of CA, Urupez II yielded FPs in the stratigraphy whose dates were consistent with other sites from the southern cone in particular, and South America in general. In addition, we can report two recently recorded FPs from the Treinta Tres department to the north and from Merín Lagoon (Rocha) that were made of quartz and a yellowish material, respectively (Figure 7(a)-(b)). One piece has a typical fishtailed ear expansion in its base, with a concave base and borders, while the other has a broad stem with almost straight parallel borders, with a slightly concave base. Another two unreported FPs that are useful for the purpose of this paper are two specimens of unknown 


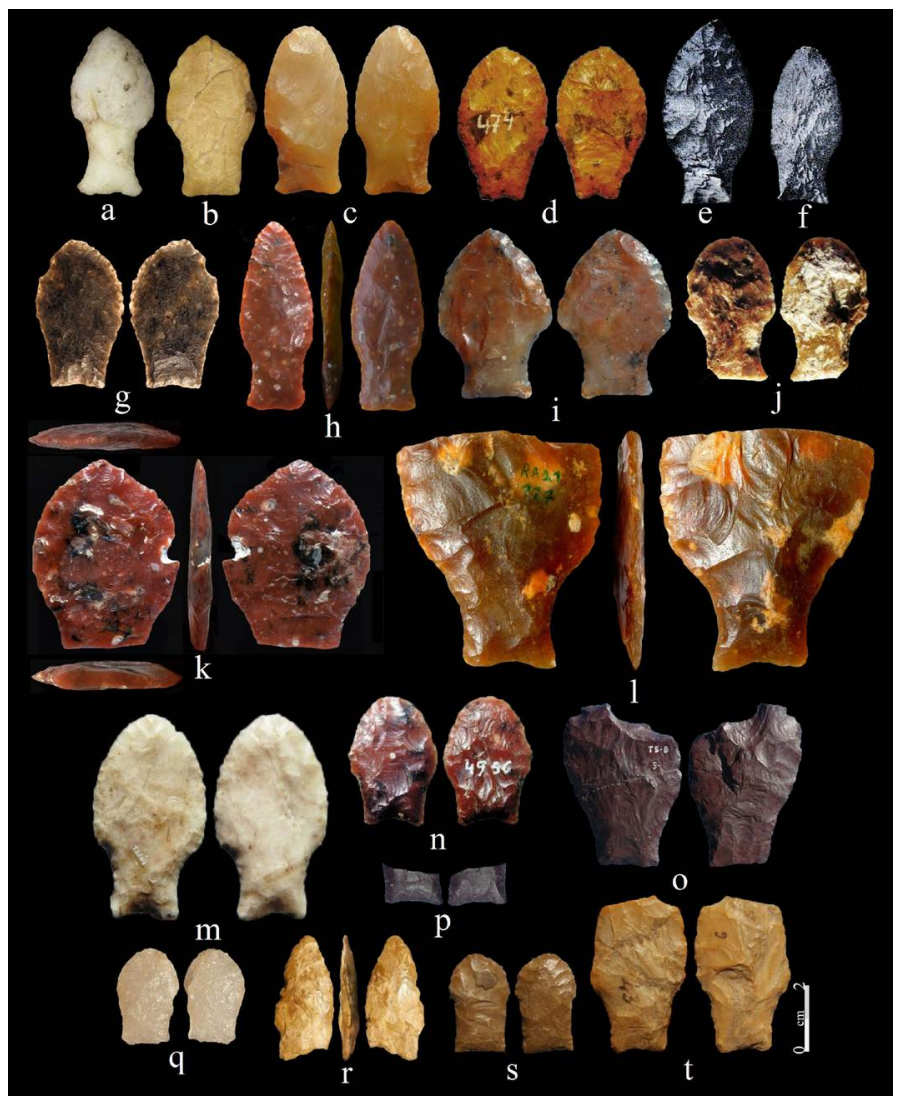

Figure 7. Fell points from the Lavalleja's neighboring departments. Treinta y Tres: (a) Ruta 17 (km 324.5); Rocha: (b) Merin Lagoon, (c) Santa Teresa, (d) Buena Vista hill, (e)-(f) Valizas (from Figueira, 1892), (g) Laguna Negra; Florida: (h) Paso de la Arena, (i) Paso de la Tranquera; Canelones: (j) Arroyo Solís chico, (k)-(l) Arroyo Vejigas, (m) Tapia, (n) Laguna Blanca; Maldonado: (o) Cerro los Burros, (p)-(r) Urupez; (s)-(t) unknown; (e)-(g) not in scale. Note the similar blade's shape in h) and r). Photographs by: a-b) R. Cáceres; (c)-(d) from Nami, 2015a: Figure e, g; (e)-(f) from Figueira, 1892; (g) Ugo Meneghin; (h)-(i), (k)-(m), (o)-(r) H. Nami; (j) and (n) J. Femenías; (s)-(t) A. Florines).

origin, but most likely come from southeastern Uruguay. They are currently in the possession of Mr. José J. Figueira, grandson of the above cited pioneer prehistorian, who at the end of the XIX century documented FPs from Rocha (Figure 7(e)-(f)). As usual with this kind of artifact, some units (e.g. Figure 7(a)-(b)) were affected by different degrees of rejuvenation (e.g., Nami, 2013, see the discussion in Loponte et al., 2015). One piece (Figure 7(s)) was probably abandoned because it shows intense, maximum, or saturated resharpening that results from the blade not having enough mass to allow this activity to continue (Nami, 2013: p. 8).

It is worth noting that in the accompanying FPs, a distinctive discoidal grindstone has been identified throughout the southern cone (Bird, 1970; Flegenheimer \& Zarate, 1990; Nami, 2013, 2017). Interestingly, in this respect, a previous 
Paleoindian discovery at Lavalleja consists of a remarkable piece (Figure 8(a)) that was found $40 \mathrm{~km}$ northwest of Cueva Amarilla. It was recovered from the Los Ciervos locality on the Santa Lucia riverbank, the natural southern border with Canelones. It came from a stratum along with the remains of extinct Late Pleistocene fauna (e.g., Glyptodon sp., Paleolama sp., Hippidion sp., and Antifer sp., among others), and tree trunks (Salix humboldtiana, Prosopis sp., PhilostylIon rhamnoies, Gletitsia amerphoides, and other unidentified species), some in an upright position (López et al., 2001; López Romanelli, 2012; Ubilla et al., 2017). Two radiocarbon dates were obtained at Los Ciervos; an AMS assay performed on an organic material sample taken from the place of the find yielded a date of 10,140 \pm 50 (Beta 301006) with a calibrated range of 11,520 - 11,500 years BP. Also, a standard radiocarbon assay from a wood specimen gave an age of $11,150 \pm 120$ (LP 1283).

In the study area, and around the cave, there are ubiquitous primary and secondary sources (see Luedtke, 1979) of lithic raw materials. The outcrops of a yellowish/pale-brown siliceous rock, commonly called "opal" or "jasper," are significant. There are also secondary sources of flakable fine-grain quartzitic rocks of different colors (among others white, green, gray, and pink), milky quartz, and quartz with a sacaroid texture. The yellowish/pale-brown material has varied fracture properties. Some samples are being used in experimental lithic research. At present, from a flintknapper's viewpoint, they can be classified as $3.5-4.0$ on an empirical grade scale from 0.5 to 5.5 (Callahan, 1979; see also Tsirk, 2014), and from "regular" to "very good" within a range from "bad" to “excellent” (Nami, 2015b). Needless to say, according to Callahan's classification heat treatment turns many rocks into a more suitable material, increasing their grade by 0.5 to 1.0 , and, under optimum conditions, an increase of 1.5 may be possible. Attempts to use this procedure on nodules obtained from the outcrops

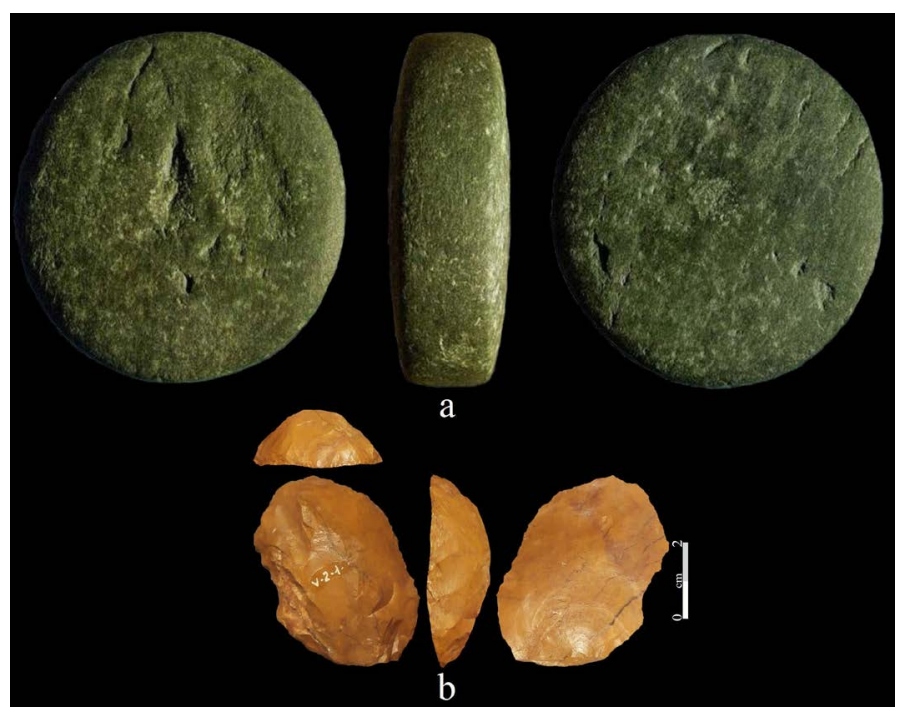

Figure 8. (a) Discoidal stone from Los Ciervos (from Nami, 2013: Figure 8(a), Figure 8 (b) scraper from Urupez (photo by H. G. Nami). 
showed the usual modifications in color and petrographic features (Crabtree \& Butler, 1964). Significantly, they became darker, and sometimes acquired a reddish tone, a fact also documented in archaeological specimens (Figure $6(\mathrm{i})-(\mathrm{m}))$. It is worth mentioning that $5 \mathrm{~km}$ northwest of CA, where thousands of artifacts have been found, La Plata is an important quarry-workshop site for this "opal" (Toscano, 1983; Nami, pers. obs. 2015). Useful to know the first stages in stone tool production (Ericson \& Purdy, 1984), the remains found at La Plata mainly consist of cores and waste, but there are also a few early-stage bifaces, thus suggesting that this part of the production process was performed at that place, as suggested by a number of archaeological, experimental, and ethno-archaeological investigations (e.g., Callahan, 1979; Binford, 1986). The surveys performed at the CA location show that this yellow rock was commonly used by hunter-gatherers living in the area (Toscano \& Florines, 2013). Significantly, during the Pleistocene-Holocene transition it was used and transported by FP makers. In fact, in the Maldonado department, debitage, and the tools to make them with, were found in Urupez (Figure 8(b)) along with FPs, one of which was made of sacaroid quartz, which also exists in the sources observed in Lavalleja (Figure $7(\mathrm{q})$ ). It is worth noting that some FPs were probably made from the aforementioned yellowish material (Figure 7(d), Figure 7(r)-(t)).

In spite of their scarcity, CA has become another example that supports the idea that rock shelters were a valuable resource for the hunter-gatherers living in the region during the last millennium of the Pleistocene (Miotti, 2010). When available in the landscape, they were used throughout the southern cone, as well as in other places in South America (Bird, 1988; Flegenheimer \& Weizel, 2017; Nami, 1996; Mazzanti et al., 2013; Yataco Capcha \& Nami, 2016). From a spatial viewpoint, the mid-eastern part of the southern cone shows that there is a definite continuity in the occupation of the mountain ranges by Late Pleistocene foragers. During the peopling process, southern Uruguay had a favorable habitat for hunter-gatherer colonizers, and the passes (abras) were a factor that influenced human and animal movements in an East-West direction (Figure 1). Consequently, CA represents another link in a chain of finds from the regional mountain ranges, and therefore peopled by hunter-gatherers bearing FPs. In fact, the Cerro los Burros and Urupez sites are located in the Sierra de las Animas near the northern shore of the paleo-riverbed of La Plata River (Cavalloto, Violante, \& Nami, 2002). South and west of this current estuary, respectively, the Ventania-Tandilia and Central mountain ranges in Argentina also yielded an important record of these colonizing human groups (Laguens et al., 2007; Rivero, 2007; Cornero et al., 2014; Mazzanti et al., 2013; Flehengeimer \& Weitzel, 2017).

\section{Concluding Remarks}

To sum up, new data on diverse Paleo American issues from Uruguay have led to a more in-depth understanding of various archaeological topics. CA is in fact 
the first cave in the country with an age of $10 \mathrm{ky}$ BP. Due to the scarcity of this sort of site, its discovery deserves attention, mainly because it makes an important contribution to the knowledge about the earliest regional hunter-gatherer occupations. Also, the recently recorded FPs found in neighboring departments has provided additional specimens that have expanded their database, and show their continuous distribution in this part of South America. In this regard, the growing information on human colonization shows that its process involved a complex scenario. In fact, most scholars now believe that the Americas were peopled more than once (Goebel et al., 2008), and that the different colonizing events produced remarkable technological and adaptive diversity, with the Pacific coast as the main initial entry route (Erlandson \& Braje, 2015, Dillehay et al., 2017). However, the Atlantic seaboard and the still-remaining Late Glacial Maximum exposed continental shelves might also have played a significant role in the expansion of the FP users (Pearson, 2004: Figure 8.5; Nami, 2016b). Due to the similarities observed between the Central and South American FPs and the fishtailed specimens from eastern, and mainly southeastern, North America, it is possible to hypothesize that there was a certain techno-morphological continuity in both areas (Faught, 2006; Nami, 2013: p. 17; Nami, 2016b). Hence, as part of the various colonization events, hunter-gatherers using "fishtailed" points in North America might have been colonizing South America by passing along the Central American isthmus and across the exposed continental shelves that existed in the Caribbean sea during the terminal Pleistocene (Nami, 2016b). During these movements, river basins and mountain ranges were probably the preferred locations for the colonizers. In this sense, CA opened a new window on diverse issues related to the earliest foragers in South America. Ongoing research will shed new light on this significant anthropological and archaeological topic.

\section{Acknowledgements}

We are indebted: to "Centro de Estudios de Ciencias Naturales Professor Francisco Oliveras" for supporting this project and radiocarbon dating; to E. Villagrán and F. Toscano for their collaboration in the field-work; to D. Hood and A. Rapalini for their help during the edition of this paper; and to R. Cáceres, J. O. Femenías (R.I.P.), J. Figueira, U. Meneghin, and R. Rodríguez for providing photographs, data and allowing us to document their collections.

\section{References}

Andrefsky, W. (2002). Lithics: Macroscopic Approaches to Analysis. Cambridge: Cambridge University Press.

Angel Ambiental (2009). Preliminary Project Area Assessment/Minas-Lavalleja-Uruguay. Sao Paulo: Unpublished Report.

Basei, M. A., Siga, O., Masquelin, H., Harara, O., Reis Neto, J. M., \& Preciozzi, F. (2000). The Dom Feliciano Belt of Brazil and Uruguay and Its Foreland Domain the Rio de la Plata Craton: Framework, Tectonic Evolution and Correlation with Similar Provinces of Southwestern Africa. Tectonic Evolution of South America, 1, 311-334. 
Bell, R. E. (1965). Archaeological Investigations at the site El Inga, Ecuador. Quito: Casa de Cultura.

Binford, L. R. (1979). Organization and Formation Processes: Looking at Curated Technologies. Journal of Anthropological Research, 35, 255-273. https://doi.org/10.1086/jar.35.3.3629902

Binford, L. R. (1986). An Alyawara Day: Making Men's Knives and beyond. American Antiquity, 51, 547-562. https://doi.org/10.2307/281751

Bird, J. (1970). Paleoindian Discoidal Stones from South America. American Antiquity, 35, 205-208. https://doi.org/10.2307/278152

Bird, J. (1988). Travels and Archaeology in South Chile. Ed. John Hyslop. Iowa City: University of Iowa Press.

Bronk Ramsey, C. (2009). Bayesian Analysis of Radiocarbon Dates. Radiocarbon, 51, 337-360. https://doi.org/10.1017/S0033822200033865

Bueno, L., Schmidt Dias, A., \& Steele, J. (2013). The Late Pleistocene/Early Holocene Archaeological Record in Brazil: A Geo-Referenced Database. Quaternary International, 301, 74-93. https://doi.org/10.1016/j.quaint.2013.03.042

Callahan, E. (1979). The Basics of Biface Knapping in the Eastern Fluted Point Tradition. A Manual for flintknappers and Lithic Analysts. Archaeology of Eastern North America, 7, 1-180.

Cassiano, G., \& Alvarez Palma, A. M. (2007). Poblamiento Clovis en la región de Meztitlan, Hidalgo, México. Arqueología, 36, 5-23.

Castiñeira, C., Cardillo, M., Charlin, J., \& Baeza, J. (2011). Análisis de morfometría geométrica en puntas cola de pescado del Uruguay. Latin American Antiquity, 22, 335-358. https://doi.org/10.7183/1045-6635.22.3.335

Cavalloto, J. L., Violante, R., \& Nami, H. G. (2002). Late Pleistocene-Holocene Paleogeography and Coastal Evolution in the Mouth of the Rio de la Plata: Implications for the Human Peopling of South America. Current Research in the Pleistocene, 19, 13-16.

Cavellini, S. (1984). Proyecto de investigación La Plata. MS Thesis, Montevideo: FHyCE.

Consens, M., López Mazz, J. M., \& Curbelo, M. (1995). Arqueología en el Uruguay. Montevideo: Surcos.

Cornero, S., Neves, W., \& Rivero, D. (2014). Nuevos aportes a la cronología de las ocupaciones tempranas en las Sierras de Córdoba. La Gruta de Candonga (Córdoba, Argentina). Relaciones de la Sociedad Argentina de Antropología, 39, 285-292.

Crabtree, D. (1972). An Introduction to Flintworking. Pocatello: Occasional Papers of the Idaho State University Museum.

Crabtree, D., \& Butler, B. (1964). Notes on Experiments in Flintknapping: 1. Heat Treatment of Silica Materials. Tebiwa, 7, 1-6.

Dias Schmidt, A. (2007). Da tipologia à tecnologia: Reflexões sobre das indústrias líticas da Tradição Umbu. In L. Bueno, \& Isnardis, A. (Eds.), Das Pedras aos Homens: Tecnologia Lítica na Arqueologia Brasileira (pp. 33-66). Belo Horizonte: Argentum Editora.

Dillehay, T., Goodbred, S., Pino, M., Vásquez Sánchez, V., Rosales Tham, T., Adovasio, V., Collins, M., Netherly, V., Hastorf, C., Chiou, K., Piperno, D., Rey, I., \& Velchoff, N. (2017). Simple Technologies and Diverse Food Strategies of the Late Pleistocene and Early Holocene at Huaca Prieta, Coastal Peru. Science Advances, 3, e1602778. https://doi.org/10.1126/sciadv.1602778

Durán Coirolo, A., \& Bracco Boksar, R. (2000). Arqueología de las Tierras Bajas. Monte- 
video: MEC.

Ericson, J., \& Purdy, B. (1984) Toward the Analysis of Lithic Production Systems. In J. Ericson, \& B. Purdy (Eds.), Prehistoric Quarries and Lithic Production (pp. 1-9). Cambridge: Cambridge University Press. https://doi.org/10.1017/CBO9780511753244.002

Erlandson, M., \& Braje, T. J. (2015). Stemmed Points, the Coastal Migration Theory, and the Peopling of the Americas. In M. Frachetti, \& R. Spengler III (Eds.), Mobility and Ancient Society in Asia and the Americas (pp. 49-58). Cham: Springer. https://doi.org/10.1007/978-3-319-15138-0_5

Faught, M. K. (2006). Paleoindian Archaeology in Florida and Panama. In J. E. Morrow, \& C. Gnecco (Eds.), Paleoindian Archaeology. A Hemispheric Perspective (pp. 164-183). Gainesville: University Press of Florida.

Feathers, J., \& Nami, H. G. (2017). Luminescence Dating of Late Pleistocene and Holocene Sediments in Uruguay.

Fernández, J. C. (1977). Apuntes para el conocimiento arqueológico del norte de Lavalleja. Actas del V Encuentro de Arqueología de Litoral. Fray Bentos: Museo Municipal de Historia Natural de Río Negro.

Figueira, J. H. (1892). Los primitivos habitantes del Uruguay. In El Uruguay en la exposición histórica americana de Madrid (pp. 121-219). Montevideo: Imprenta Artística Americana de Dornaleche y Reyes.

Flegenheimer, N., \& Weitzel, C. (2017). Fishtail Points from the Pampas of South America: Their Variability and Life Histories. Journal of Anthropological Archaeology, 45, 142-156. https://doi.org/10.1016/j.jaa.2016.12.001

Flegenheimer, N., \& Zárate, M. (1990). Paleoindian Occupations at Cerro El Sombero Locality, Buenos Aires Province, Argentina. Current Research in the Pleistocene, 6, 12-13.

Goebel, T., Waters, M. R., \& O’Rourke, D. H. (2008). The Late Pleistocene Dispersal of Modern Humans in the Americas. Science, 319, 1497-1502. https://doi.org/10.1126/science.1153569

Graf, K. E., Ketron, C. V., \& Waters, M. R. (2013). Paleoamerican Odissey. College Station, TX: Center for the Study of the First Americans.

Hester, T. R., \& Heizer, R. F. (1972). Problems in the Functional Interpretation of Artifacts: Scraper Planes from Mitla and Yagul, Oaxaca. Contributions of the University of California Archaeological Research Facility. Miscellaneous Papers on Archaeology, No. 14, 107-123.

Hilbert, K. (1985). Archaelogische fundplatze des Río Uruguay, tigre und des Mandiyú, Republik Uruguay. Beitrage zur Allgemeinen und Vergleichenden Archaeologie, 7, 447-561.

Hogg, A. G., Quan, H., Blackwell, P. G., Mu, N., Buck, C. E., Guilderson, T. P., Heaton, T. J., Palmer, J. G., Reimer, P. J., Reimer, R. W., Turney, C. S., \& Zimmerman, S. R. H. (2013). SHCal13 Southern Hemisphere Calibration, 0-50,000 Years cal BP. Radiocarbon, 55, 1889-1903. https://doi.org/10.2458/azu_js_rc.55.16783

Laguens, A., Pautassi, E., Sario, G., \& Cattáneo, R. (2007). Fishtail Projectile Points from Central Argentina. Current Research in Pleistocene, 24, 55-57.

López Mazz, J., Gascue, A. A., \& Moreno, R. F. (2003-2004). La prehistoria del este de Uruguay: Cambio cultural y aspectos ambientales. Anales de Prehistoria y Arqueología, 19-20, 9-24.

López Romanelli, F. (2012). El yacimiento "Los Ciervos": Hallazgos paleontológicos y arqueológicos en sedimentos de la transición Pleistoceno-Holoceno (Depto. de Lavalleja, 
Uruguay). Orígenes, 11, 1-16.

López, F., Femenías, J., \& Nami, H. G. (2001). Fell Evidence and New Data on Late-Pleistocene Landscape from Canelones, Uruguay. Current Research in the Pleistocene, 18, 41-44.

López-Mazz, J. M. (2013). Early Human Occupation of Uruguay: Radiocarbon Database and Archaeological Implications. Quaternary International, 301, 94-103. https://doi.org/10.1016/j.quaint.2012.07.004

Loponte, D., \& Carbonera, M. (2017). Paleoamericans in Northeast Argentina. Archaeological Discovery, 5, 79-94. https://doi.org/10.4236/ad.2017.52005

Loponte, D., Carbonera, M., \& Silvestre, R. (2015). Fishtail Projectile Points from South America: The Brazilian Record. Archaeological Discovery, 3, 85-103. https://doi.org/10.4236/ad.2015.33009

Loponte, D., Okumura, M., \& Carbonera, M. (2016). New Records of Fishtail Projectile Points from Brazil and Its Implications for Its Peopling. Journal of Lithic Studies, 3, 63-85. https://doi.org/10.2218/jls.v3i1.1312

Luedtke, B. (1979). The Identification of Sources of Chert Artifacts. American Antiquity 44, 744-757. https://doi.org/10.2307/279116

Maggard, G., \& Dillehay, T. D. (2011). El Palto Phase (13800-9800 BP). In T. Dillehay (Ed.), From Foraging to Farming in the Andes: New Perspectives on Food Production and Social Organization (pp. 77-94). Cambridge: Cambridge University Press. https://doi.org/10.1017/CBO9780511793790.005

Mazzanti, D. L., Martínez, G., Colobig, M., Zucol, A. F., Passeggi, E., Brea, M., Bonnat, G. F., Hassan, G., Soria, J. L., Vera, J., \& Quintana, C. (2013). Avances en los estudios arqueológicos, geoarqueológicos y paleoambientales en las Sierras Orientales de Tandilia. Resultados preliminares de los sitios Alero El Mirador y Abrigo La Grieta. Revista del Museo de La Plata (Antropología), 13, 59-76.

Meltzer, D. (2013). The Human Colonization of the Americas: Archaeology. In I. Ness (Ed.), The Encyclopedia of Global Human Migration. Wiley-Blackwell. https://doi.org/10.1002/9781444351071.wbeghm808

Meneghin, U. (2015). Secuencia Crono-estratigráfica de Urupez II: Nuevas dataciones radiométricas. Orígenes, 13, 1-20.

Miller, E. T. (1987). Pesquisas arqueológicas paleoindígenas no Brasil Ocidental. Estudios Atacamenos, 8, 37-61. https://doi.org/10.22199/S07181043.1987.0008.00005

Miotti, L. (2010). Cuevas y abrigos rocosos: Nudos de las redes sociales entre los cazadores-recolectores del Maciso del Deseado, Patagonia extra-andina. In J. C. Giménez López, C. Serrano Sánchez, A. González González, \& F. J. Aguilar Arellano (Eds.), III simposio internacional El Hombre temprano en América (pp. 147-174). México D.F.: Instituto Nacional de Antropología e Historia, Instituto de Investigaciones Antropológicas, UNAM.

Moreno de Sousa, J. C. (2017). Paleoindian Lithic Industries of Southern Brazil: A Technological Study of the Laranjito Archaeological Site, Pleistocene-Holocene Transition. PaleoAmerica, 3, 74-83. https://doi.org/10.1080/20555563.2016.1248752

Nami, H. G. (1996). New Assessments of Early Human Occupations in the Southern Cone. In T. Akazawa, \& E. J. Szathmáry (Eds.), Prehistoric Mongloid Dispersals (pp. 254-269). Oxford: Oxford University Press.

Nami, H. G. (2007). Research in the Middle Negro River Basin (Uruguay) and the Paleoindian Occupation of the Southern Cone. Current Anthropology, 48, 164-176. https://doi.org/10.1086/510465 
Nami, H. G. (2010). Tecnología Paleoindia de Sudamérica: Nuevos experimentos y observaciones para conocer la secuencia de reducción Fell. Origenes, 9, 1-40.

Nami, H. G. (2013). Archaelogy, Paleoindian Research and Lithic Technology in the Middle Negro River, Central Uruguay. Archaeological Discovery, 1, 1-22. https://doi.org/10.4236/ad.2013.11001

Nami, H. G. (2014). Arqueología del último milenio del Pleistoceno en el Cono Sur de Sudamérica, puntas de proyectil y observaciones sobre tecnología Paleoindia en el Nuevo Mundo. In M. Farias, \& A. Lourdeau (Eds.), Peuplement et Modalités d'Occupation de l'Amérique du Sud: L'Apport de la Technologie Lithique (pp. 279-336).Prigonrieux: @rchéo-éditions.com.

Nami, H. G. (2015a). New Records and Observations on Paleo-American Artifacts from Cerro Largo, Northeastern Uruguay and a Peculiar Case of Reclaimed Fishtail Points. Archaeological Discovery, 3, 114-127. https://doi.org/10.4236/ad.2015.33011

Nami, H. G. (2015b). Experimental Observations on Some Non-Optimal Materials from Southern South America. Lithic Technology, 40, 128-146. https://doi.org/10.1179/2051618515Y.0000000004

Nami, H. G. (2016a). Silcrete as a Valuable Resource for Stone Tool Manufacture and Its Use by Paleo-American Hunter-Gatherers in Southeastern South America. Journal of Archaeological Science: Reports, 15, 539-560. https://doi.org/10.1016/j.jasrep.2016.05.003

Nami, H. G. (2016b). Paleo American Finds from Venezuela: Evidence to Discuss the Spread of Fell Points and the Peopling of Northern South America. Cadernos do CEOM, 29, 121-128. https://doi.org/10.22562/2016.45.08

Nami, H. G. (2017). Hallazgos Paleoindios en Dolores, departamento de Soriano, Uruguay. Cuadernos del Instituto Nacional de Antropología y Pensamiento Latinoamericano.

Nami, H. G., \& Stanford, D. J. (2016). Dating the Peopling of Northwestern South America: An AMS Date from El Inga Site, Highland Ecuador. PaleoAmerica, 2, 60-63. https://doi.org/10.1080/20555563.2016.1139793

Pearson, G. A. (2004). Pan-American Paleoindian Dispersals and the Origins of Fishtail Projectile Points as Seen through the Lithic Raw-Material Reduction Strategies and Tool-Manufacturing Techniques at the Gardiría Site, Turrialba Valley, Costa Rica. In C. M. Barton, G. A. Clark, D. Yesner, \& G. Pearson (Eds.), The Settlement of the American Contiments (pp. 85-102). Tucson: University of Arizona Press.

Prates, L., Politis, G., \& Steele, J. (2013). Radiocarbon Chronology of the Early Human Occupation of Argentina. Quaternary International, 104-122

Rivero, D. (2007). Los primeros pobladores de las Sierras Centrales de Argentina. Comechingonia Virtual, 1, 32-51.

Salls, R. A. (1985). The Scraper Plane: A Functional Interpretation. Journal of Field Archaeology, 12, 99-106.

Sánchez Bettucci, L. (1998). Evolución tectónica del Cinturón Dom Feliciano en la región Minas-Piriápolis, Uruguay. Doctoral Dissertation. FCEN, Universidad de Buenos Aires, Buenos Aires.

Suárez, R. (2015). The Paleoamerican Occupation of the Plains of Uruguay: Technology, Adaptations, and Mobility. PaleoAmerica, 1, 88-104. https://doi.org/10.1179/2055556314Z.00000000010

Toscano, A. (1983) Sitio arqueológico La Plata. In A. Barrios Pintos (Ed.), Minas, dos siglos de su historia (Vol. 1, pp. 44-48). Montevideo: MEC. 
Toscano, A., \& Florines, A. (2013). Informe Final de Actuación Arqueológica Parque Eólico Sierras de Minas, Lavalleja. Generación Eólica Minas S.A. Akuo Energy.

Tsirk, A. (2014). Fractures in Knapping. Oxford: Archaeo Press.

Ubilla, M., Rinderknecht, A., Corona, A., \& Perea, D. (2017). Mammals in Last 30 to 7 ka Interval (Late Pleistocene-Early Holocene) in Southern Uruguay (Santa Lucía River Basin): Last Occurrences, Climate, and Biogeography. Journal of Mammalian Evolution, 1-10. https://doi.org/10.1007/s10914-017-9380-2

Waters, M. R., \& Stafford, T. (2007). Redefining the Age of Clovis: Implications for the Peopling of the Americas. Science, 315, 1122-1126. https://doi.org/10.1126/science.1137166

Waters, M. R., Amorosi, T., \& Stafford, T. (2015). Redating Fell's Cave, Chile and the Chronological Placement of The Fishtail Projectile Point. American Antiquity, 80, 376-386. https://doi.org/10.7183/0002-7316.80.2.376

Yataco Capcha, J., \& Nami, H. G. (2016). A Re-Evaluation of Paleo-American Artifacts from Jaywamachay Rockshelter, Ayacucho Valley, Peru. PaleoAmerica, 2, 368-372.

https://doi.org/10.1080/20555563.2016.1199198 